\title{
A MONTHLY-STEP WATER BALANCE MODEL TO EVALUATE THE HYDROLOGICAL EFFECTS OF CLIMATE CHANGE ON A REGIONAL SCALE FOR IRRIGATION DESIGN
}

A. HERCEG ${ }^{*}$, P. KALICZ1' B. KISFALUDI', Z. GRIBOVSZKI ${ }^{1}$

\begin{abstract}
Current and ongoing changes in the climate are typified by a rise in global temperatures. Climate change can have a dramatic impact on the water cycle. The aim of this paper was to develop a model based on Thornthwaite-type monthly water balance estimations. The main goals were to calibrate the model parameters using a remote sensing-based evapotranspiration dataset. The calibrated model was used for projection on the basis of four climate model datasets (remo, dmihirham5, smhirca.bcm, knmiracmo2). The four main projection periods were: 1980-2010, 2010-2040, 20402070, and 2070-2100. The advantage of this model is its robust structure. It can be applied if temperature and precipitation time series are available. The key parameter is the water storage capacity of the soil (SOILMAX), which can be calibrated using the actual evapotranspiration data available. If the physical properties of the soil are known, the maximal rooting depth is also projectable. The model can be primarily used at the catchment level or for areas without additional amounts of water from below. For testing the model, a mixed parcel of land that is used as a cornfield near Mosonmagyaróvár and a small, forest-covered catchment near Sopron were successfully used as the datasets. Furthermore, we determined the water stress with the calculation of the relative extractable water (REW), soil water deficit (SWD), and the water stress index (IS).
\end{abstract}

Address

1 Institute of Geomatics and Civil Engineering, University of West Hungary, Ady Endre u. 5. Sopron H-9400, Hungary

* Corresponding author: herceg.andras88@gmail.com

\section{Key words}

- Monthly water balance,

- Climate change,

- Eevapotranspiration / soil moisture.

\section{INTRODUCTION}

Globally, circa $62 \%$ of the precipitation that falls on the continents is evapotranspired; hence, the necessity of modelling and attaining a quantitative understanding of the evapotranspiration (ET) process is unquestionable, especially in the context of climate change projections (Dingman, 2002).

In Hungary, the evapotranspired rate for fallen precipitation is $90 \%$, while the remaining $10 \%$ is runoff (Kovács, 2011). In addition, ET exceeds runoff on all the continents except Antarctica (Dingman,
2002). Therefore, evapotranspiration plays an important role in the availability of water on the surface of land, thereby controlling the large-scale distribution of plants and primary production (e.g., Neilson, 1995; Vörösmarty et al., 1998). Evapotranspiration also plays a key role in runoff and the availability of water in agriculture. Most of the world's food supply is grown on irrigated land; thus, efficient irrigation requires a knowledge of transpiration (Dingman, 2002). Although evapotranspiration is a major component of the hydrologic water balance, it is not well understood (Wilson et al., 1992).

The direct measurement of evapotranspiration is difficult, im- 
practical and expensive. As a result, PET-based (potential evapotranspiration) methods are the most popular ways to estimate evapotranspiration (Dingman, 2002).

Current and ongoing changes in the climate are typified by a rise in global temperatures. There was a $0.6^{\circ} \mathrm{C}$ increase in temperatures during the 20th century with an even greater increase in recent decades (IPCC, 2014).

Baseline scenarios, i.e., those without additional mitigation, will result in global mean surface temperature increases from $3.7^{\circ} \mathrm{C}$ to 4.8 ${ }^{\circ} \mathrm{C}$ by 2100 compared to pre-industrial levels (IPCC, 2014).

In Hungary, the ongoing warming process in question was the most intense in the last 30 years. During these past 30 years, the most notable increase in temperatures occurred during the summer, when temperatures have risen by as much as $2{ }^{\circ} \mathrm{C}$ (Bartholy et al., 2011, HREX, 2012).

The most significant effect of climate change is its impact on the water cycle through altering precipitation patterns and evapotranspiration processes on multiple scales (Sun et al., 2008; Szilágyi and Józsa, 2008; Hlavčová et. al., 2015).

Climate change induces extreme weather conditions and changes in the distribution of annual precipitation. These changes in distribution often result in an increase in the amount of precipitation within a single precipitation event; however, the rainfall depth remains nearly equal. In Hungary, extreme conditions have become more prevalent in the last 30 years, and this tendency will continue in the $21^{\text {st }}$ century (Gálos and Vig, 2014) (HREX, 2012).

To explore the above data, climate models, which are mathematical representations of the climate, have to be used. The models divide the Earth's atmosphere and oceans into a grid. For each point on the grid, the models calculate the values of the projected variables over time, i.e., surface pressure, temperature, wind, humidity and rainfall. The best known climate models are the "atmospheric general circulation models" (GCMs) [1].

A significant limitation of GCMs is the relatively rough horizontal resolution. Thus, for local issues, countries require information on a finer spatial scale. Regional models (RCMs) are able to offer a useful solution to this resolution problem [1].
Our main goal was to reveal the impact of climate change on the agrarian and forestry sectors (for areas that do not have or receive additional amounts of water from below the surface); a demand has emerged for a monthly water balance model. In this paper, the water balance refers to the components of soil moisture and the actual evapotranspiration. The Agrárklíma. 2 project's database (temperature and precipitation data) and remote sensed actual evapotranspiration data were used to establish the model. The latter originated from Szilágyi and Kovács (2010) and Kovács (2011).

The water balance base model was made by C. W. Thornthwaite (Thornthwaite, 1955). We created our own new model by upgrading and adapting Thornthwaite's monthly balance model.

\section{STUDY AREA}

To test our model, we used two study areas, i.e., a forested area and a mixed parcel of land, situated in the Western Transdanubian Region of Hungary (Figure 1).

The forested area is an experimental catchment at the eastern foothills of the Alps near the city of Sopron. The climate of this area is subalpine. The daily mean temperature is $0{ }^{\circ} \mathrm{C}$ in the winter and $17^{\circ} \mathrm{C}$ in the summer. The annual precipitation is $750 \mathrm{~mm}$. The driest season is autumn, while the wettest part of the year is late spring and early summer (Marosi-Somogyi, 1990). The geological basis of the catchment is fluvial sediments, which were deposited in five distinct layers in the tertiary (Miocene) period on crystalline bedrock. A finer-grained layer appears in the valley bottom, which is a good aquifer that gives rise to perennial streams (Kisházi-Ivancsics, 1985). The soil texture of this area is loam. The dominant vegetation in the catchment comprises alder (Alnusglutinosa (L.) Gaertn.) in the bottom of the valley, spruce (Picea Abies) and beech (Fagus sylvatica) on the northern slopes, and sessile oak (Quercus petraea) and beech (Fagus sylvatica) on the southern slopes.

The mixed parcel of land is basically used as an agricultural plot and has primarily been a cornfield except during a period between 2003 and 2007, when it was used to grow barley, and in 2004, when it

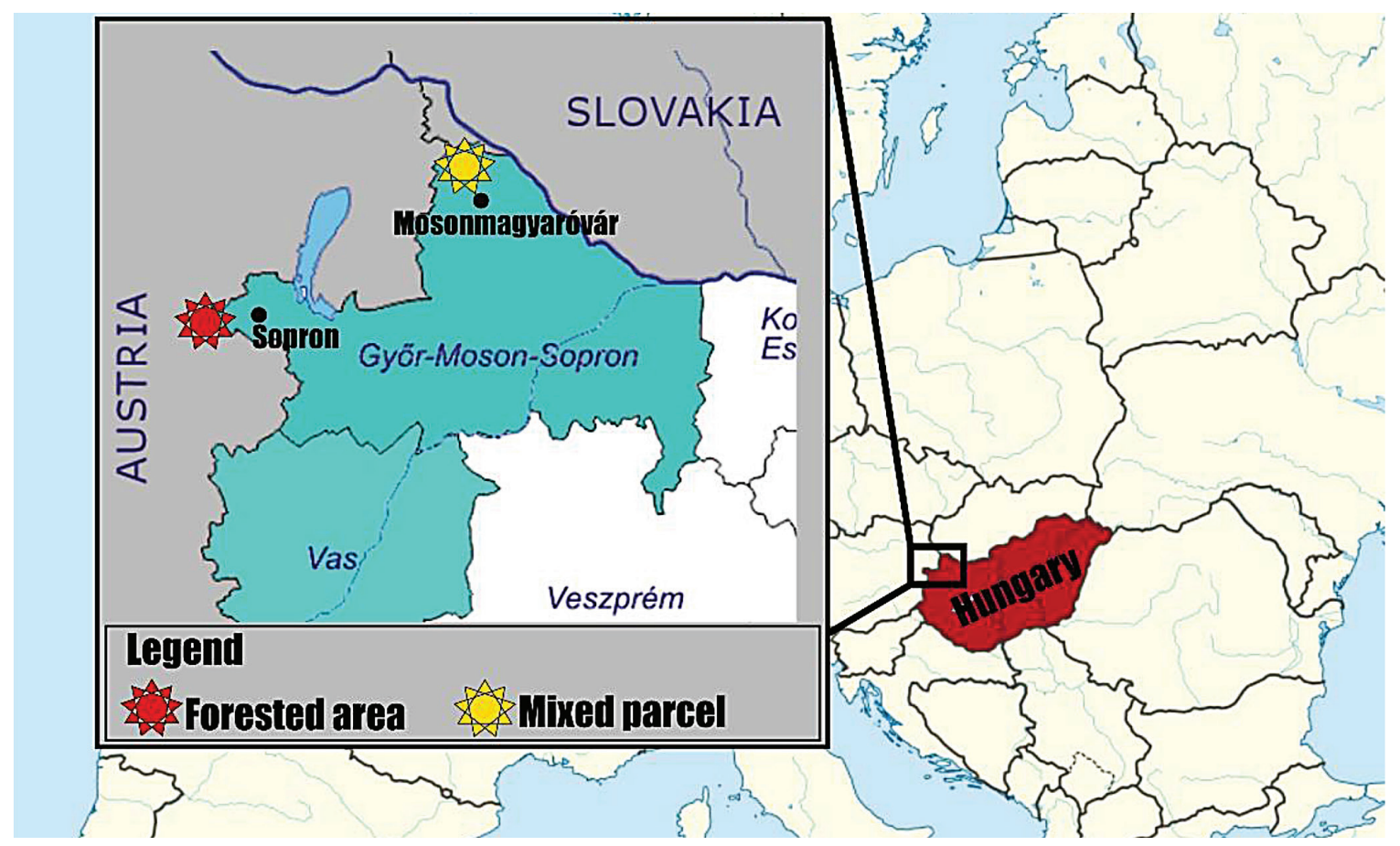

Fig. 1: Our study areas. (The coordinates of the study areas are the following: 47 40'11.3' $N$; $16^{\circ} 27^{\prime} 31.1$ ' $E$ (forested area) and $47^{\circ} 54^{\prime} 19,20^{\prime \prime} N$; $17^{\circ} 15^{\prime} 09,89^{\prime \prime}$ ). 
was used for wheat. It has a total area of about $1 \mathrm{~km}^{2}$. However, poplar species can also be found on this $1 \times 1 \mathrm{~km}$ area, which is why we use the term 'mixed parcel' rather than 'cornfield' for this study area.

The parcel in question is located in the Mosoni-sík microregion, which is situated in Györ-Moson-Sopron County. It is essentially (73.5\%) ploughland. This natural microregion is an alluvial plain as a whole. In the context of geology, the area is the southern accumulation slope of the wash of the Danube, which was built on the sinking recess of the Little Hungarian Plain. In the north-western part of the natural microregion, the surface is covered by recent fluvial siltand fluvial cobble on the two sides of the Lajta, but south and southeast of that region, the surface is covered by muddy-loessal sedimentary cover.

The climate is continental. There is a difference between the western and eastern parts of the natural microregion in the context of temperature. Consequently, the average annual temperature is $9.7^{\circ} \mathrm{C}$ in the western part, but $10.0^{\circ} \mathrm{C}$ in the eastern part.

Hydromorphic soil, which evolved on cobble, characterizes the natural microregion. The ratio of a plantation of aspen is significant in the natural microregion (Dövényi, 2010).

\section{METHODS}

Hydrologists use Thornthwaite-type water balance models for steady-state seasonal (climatic average) simulations and also to study the continuous values of a watershed or a region's water input, snowpack, soil moisture, and evapotranspiration. The inputs are the monthly precipitation $\left(\mathrm{P}_{\mathrm{M}}\right)[\mathrm{mm}]$ and temperature $\left(\mathrm{T}_{\mathrm{M}}\right)\left[{ }^{\circ} \mathrm{C}\right]$ values in these kinds of models (Dingman, 2002).

Remote sensing-based evapotranspiration data were used for calibration of a modified version of the original Thornthwaite model (Dingman, 2002; Kovács, 2011).

Based on Bouchet's (1963) complementary relationship, Morton et al. (1985) presented the WREVAP model for estimating regionally representative actual evapotranspiration rates for periods longer than 5 days. Szilágyi et al. (2011) established a method called CREMAP to downscale the regional actual evapotranspiration values into spatially variable actual evapotranspiration rates. Kovács (2011) mapped the monthly actual evapotranspiration ( $\mathrm{ET}_{\text {CREMAP }}$ ) for Hungary from 2000 to 2008 using the Szilágyi CREMAP method.

The basis of the method is a linear transformation. This transformation uses the 8-day composited (Moderate Resolution Imaging Spectroradiometer) MODIS daytime surface temperature (Ts) values into actual evapotranspiration rates (Szilágyi and Józsa, 2009). These actual monthly evapotranspiration maps were prepared from March till November each year.

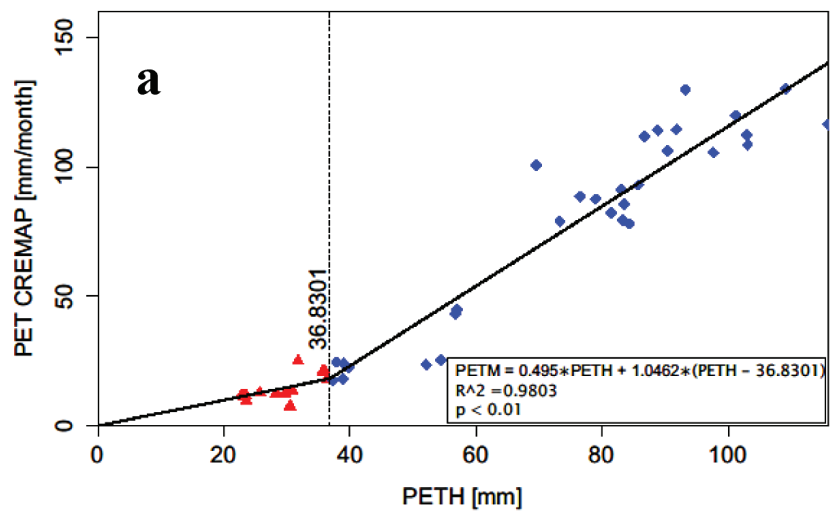

The time period for the model's calibration was from 2000 to 2008. The calibration was divided into two main parts: the calibration of the potential evapotranspiration and the calibration of the actual evapotranspiration.

\subsection{Calibration of the potential evapotranspiration}

The first step in setting up the model is the calculation of the potential evapotranspiration (PET $\left[\mathrm{mm} \cdot \mathrm{day}^{-1}\right]$ ). Potential evapotranspiration is the rate at which evapotranspiration would occur from a large area that is uniformly and completely covered with growing vegetation that has access to an unlimited supply of soil water, without advection or the heat storage effect (Dingman, 2002). The concept was introduced for climate classifications by Thornthwaite (1948).

According to Hamon (1963), we used a temperature-based PET model for the calculations ( $\mathrm{PET}_{\mathrm{H}}$ ).

$$
\begin{gathered}
\mathrm{e}_{\mathrm{m}}{ }^{*}=0,611 \cdot \exp \left(\frac{17,3 \cdot \mathrm{T}_{\mathrm{m}}}{\mathrm{T}_{\mathrm{m}}+237,3}\right) \\
\mathrm{PET}_{\mathrm{H}}=29,8 \cdot \mathrm{D} \frac{\mathrm{e}_{\mathrm{m}}^{*}}{\mathrm{~T}_{\mathrm{m}}+273,2}
\end{gathered}
$$

where:

D: day length $[\mathrm{hr}]$

$\mathrm{T}_{\mathrm{m}}$ : the average monthly temperature $\left[{ }^{\circ} \mathrm{C}\right]$

$\mathrm{e}_{\mathrm{m}}{ }^{*}$ : saturation vapor pressure $[\mathrm{kPa}]$.

The daily $\mathrm{PET}_{\mathrm{H}}$ unit has to be aggregated into $\left[\mathrm{mm} \cdot \mathrm{month}^{-1}\right]$.

The next step was the calibration of the $\mathrm{PET}_{\mathrm{H}}$ for the actual land cover using the $\mathrm{ET}_{\text {CREMAP }}[\mathrm{mm}]$ values of a given pixel at a well-watered condition. The well-watered condition was defined by the following criteria for the given month: the data (months) when precipitation exceeded the values of the potential evapotranspiration $\left(\mathrm{PET}_{\mathrm{H}}\right)$, or when the actual evapotranspiration $\left(\mathrm{ET}_{\mathrm{CREMAP}}\right)$ exceeded the values of the potential evapotranspiration $\left(\mathrm{PET}_{\mathrm{H}}\right)$ :

$$
\mathrm{P}_{\mathrm{M}}>\mathrm{PET}_{\mathrm{H}} \text { or } \mathrm{ET}_{\text {CREMAP }}>\mathrm{PET}_{\mathrm{H}}
$$

Between the $\mathrm{ET}_{\text {CREMAP }}$ and $\mathrm{PET}_{\mathrm{H}}$ monthly values selected, we established the regression. The selected $\mathrm{ET}_{\text {CREMAP }}$ values are called

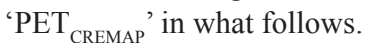

In the chosen months the response variable was the actual evapotranspiration $\left(\mathrm{ET}_{\mathrm{CREMAP}}\right)$, and $\mathrm{PET}_{\mathrm{H}}$ was the explanatory variable. The potential evapotranspiration values of the growing season and the dormant season are different because of the variant states of the vegetation. Therefore, different regressions have to be used for the dormant season and the growing season. To accomplish this separation, we used a package called 'segmented' (Muggeo, 2008) in the ' $R$ ' program, which is a free software environment for statistical compu-

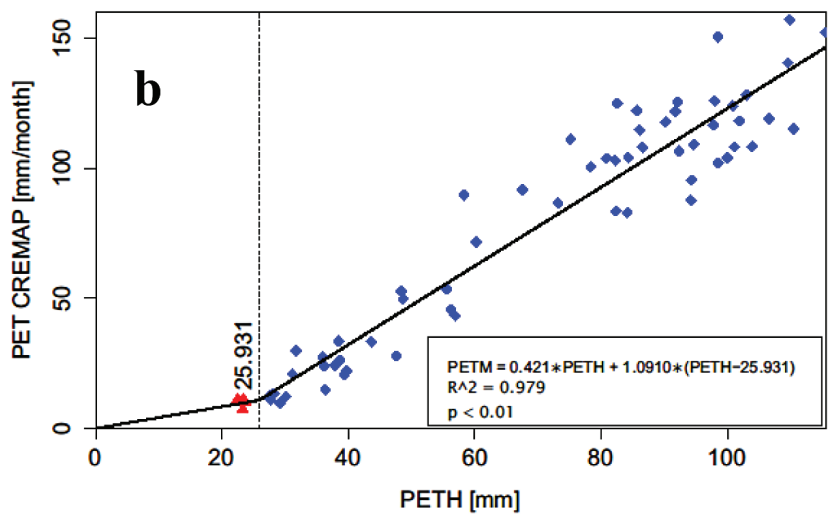

Fig. 2: Relationship between PET $T_{C R E M A P}$ and PET $T_{H}$ in growing and dormant seasons for the mixed parcel (a) and the forested area (b). 
Tab. 1: Results of the broken-line regression for the mixed parcel and forested area.

\begin{tabular}{|c|c|c|c|c|c|}
\hline Study areas & & Estimate & Std. Error & t value & $\operatorname{Pr}(>|\mathbf{t}|)$ \\
\hline \multirow{2}{*}{ Mixed parcel } & Slope of the first segment & 0.495 & 0.0961 & 5.145 & $>0.001$ \\
\cline { 2 - 7 } & Slope of the second segment & 1.0462 & 0.128 & 8.153 & NA \\
\hline \multirow{2}{*}{ Forested area } & Slope of the first segment & 0.421 & 0.284 & 1.477 & $>0.001$ \\
\cline { 2 - 7 } & Slope of the second segment & 1.0910 & 0.291 & 3.760 & NA \\
\hline
\end{tabular}

The reason for the 'NA' of the ' $\operatorname{Pr}(>|t|)$ 'in Table 1 is that the standard asymptotics are not applicable.

ting and graphics (R Core Team, 2012). To establish these different relationships for the growing and dormant seasons, we had to use broken-line or segmented models. These models create a piecewise linear relationship between the response and one or more of the explanatory variables. This linear relationship is represented by two or more straight lines connected at unknown values called breakpoints (Muggeo, 2008). Figure 2 shows the results of the broken-line models.

Using the parameters of Table 1, we calculated the calibrated potential evapotranspiration values $\left(\mathrm{PET}_{\mathrm{M}} ;[\mathrm{mm}]\right)$ for our model. We did not take into consideration the accumulation and melting effect of the snow. Due to the higher expected temperatures in the future, the chance of having permanent (stable) snow cover (remaining continuously for at least a month) will likely decrease in Hungary.

\subsection{Calibration of the actual evapotranspiration}

The next step was the calibration of the actual evapotranspiration $\left(\mathrm{ET}_{\mathrm{M}} ;[\mathrm{mm}]\right)$. The calibration parameter was the soil-water storage capacity of the soil (SOIL $\left.{ }_{\text {MAX }}[\mathrm{mm}]\right)$ (Dingman, 2002).

If:

$$
\mathrm{P}_{\mathrm{M}} \geq \mathrm{PET}_{\mathrm{M}}
$$

(where $\mathrm{M}$ means the actual month), then:

$$
\mathrm{ET}_{\mathrm{M}}=\mathrm{PET}_{\mathrm{M}}
$$

In this case the monthly soil moisture $\left(\operatorname{SOIL}_{M}[\mathrm{~mm}]\right)$ can be calculated as follows:

$$
\mathrm{SOIL}_{\mathrm{M}}=\min \left\{\left[\left(\mathrm{P}_{\mathrm{M}}-\mathrm{ET}_{\mathrm{M}}\right)+\mathrm{SOIL}_{\mathrm{M}-1}\right], \mathrm{SOIL}_{\mathrm{MAX}}\right\}
$$

The first $\mathrm{SOIL}_{\mathrm{M}-1}$ value was set at the maximum $\left(\mathrm{SOIL}_{\mathrm{MAX}}\right)$ because the modelling period started in dormancy. That first value was adjusted to the soil type with a standard setting of the rooting depth (1 $\mathrm{m})$. The equation for the $\mathrm{SOIL}_{\mathrm{MAX}}$ is:

$$
\operatorname{SOIL}_{\mathrm{MAX}}=\left(\theta_{\mathrm{fc}}-\theta_{\mathrm{pwp}}\right) * \mathrm{z}_{\mathrm{rz}}
$$

where:

$\Theta_{\mathrm{fc}}$ : field capacity [dimensionless],

$\Theta_{\text {pwp }}:$ permanent wilting point [dimensionless],

$\mathrm{z}_{\mathrm{rz}}$ : rooting depth (vertical extent of root zone $[\mathrm{mm}]$ ).

Considering the soil sampling results, there is sandy loam soil on both case of the study areas, therefore we have applied 0.207 as $\Theta_{\mathrm{fc}}$, and 0.095 as $\Theta_{\text {pwp }}$ (Maidment, 1993).

If the precipitation in the actual month is less than the calibrated potential evapotranspiration,

$$
\mathrm{P}_{\mathrm{M}}<\mathrm{PET}_{\mathrm{M}}
$$

then:

$$
\mathrm{ET}_{\mathrm{M}}=\mathrm{P}_{\mathrm{M}}+\mathrm{SOIL}_{\mathrm{M}-1}-\mathrm{SOIL}_{\mathrm{M}}=\mathrm{P}_{\mathrm{M}}+\Delta \mathrm{SOIL}
$$

where:

$\Delta$ SOIL $=$ SOIL $_{M-1}-$ SOIL $_{M}=\operatorname{SOIL}_{M-1} *\left(1-\exp \left(-\frac{\text { PET }_{M}-\mathrm{P}_{\mathrm{M}}}{\text { SOIL }_{\mathrm{MAX}}}\right)\right)$

$\Delta$ SOIL: decrease in soil storage [mm].

The initially estimated $\mathrm{SOIL}_{\mathrm{MAX}}$ parameter has to be adjusted with iterations while we reach the maximal correlation between $\mathrm{ET}_{\text {CREMAP }}$ and $\mathrm{ET}_{\mathrm{M}}$. To achieve this maximum correlation, we used the 'optim' function of the ' $\mathrm{R}$ ' software. This function optimizes searches for the intervals from lower to upper for a minimum or maximum of the function $f$ with respect to its first argument.

After the calibration, the relationship between $\mathrm{ET}_{\mathrm{M}}$ and $\mathrm{ET}_{\mathrm{CREMAP}}$ can be characterized with the following $\mathrm{R}^{2}$ (the coefficient of determination) values: 0.748 (mixed parcel) and 0.899 (forested area). Consequently, the model is reliable. For the forested area we achieved a better correlation in the calibration phase, which may be the result of the more homogenous and continuously similar surface covers (nearly $100 \%$ forested).

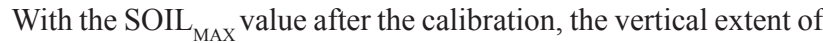
the root zone (and the maximum depth of the tilth) can be calculated using the soil texture data. In the case of the mixed parcel, the calibrated SOIL MAX $=276.85 \mathrm{~mm}$, while in the case of the forested area, SOIL $_{\mathrm{MAX}}=502.55 \mathrm{~mm}$. Considering the previously recorded facts and eq. (7), the vertical extent of the root zone is $2472 \mathrm{~mm}$ in the case of mixed parcel and $4487 \mathrm{~mm}$ in the case of the forested area. Soil sampling of the mixed parcel showed the extent of the roughly $2.5 \mathrm{~m}$ root zone, which ends in a sandy loam layer.

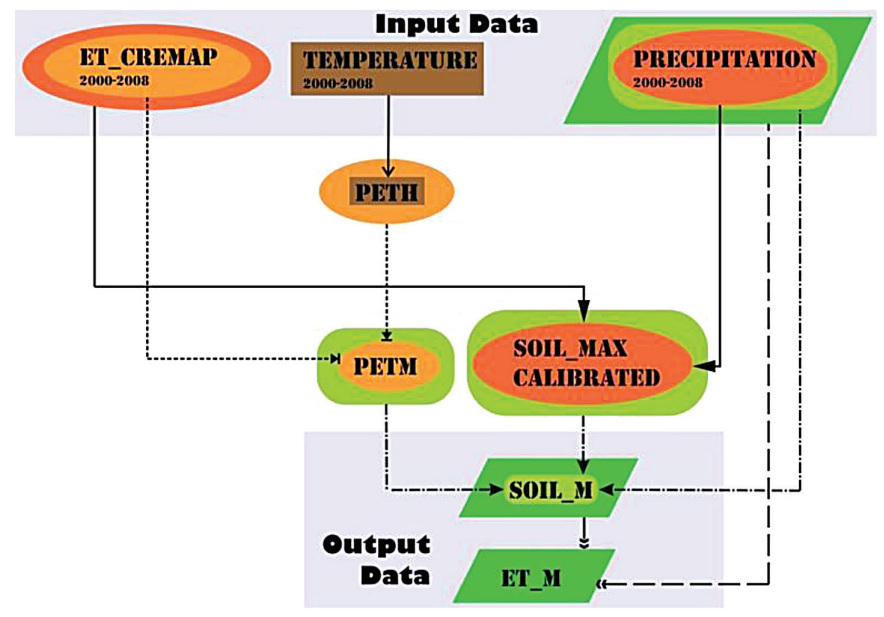

Fig. 3: Graphic representation of the model. 

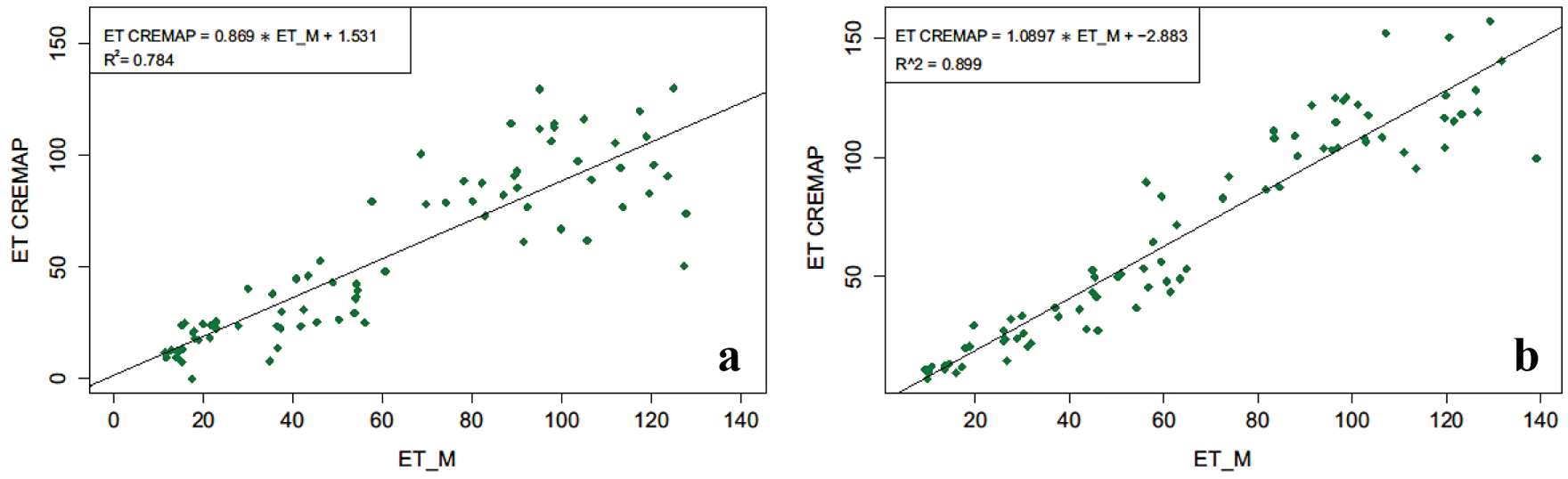

Fig. 4: Relationship between $E T_{M}$ and $E T_{C R E M A P}$; the calibrated model for the mixed parcel (a) and forested area (b).

Tab. 3: Changes in the temperature and precipitation of the regional climate models from 1980 to 2100 with the standard deviations.

\begin{tabular}{|c|c|c|c|c|c|c|c|c|}
\hline \multirow{2}{*}{ RCMs } & $\mathbf{1 9 8 0 / 2 0 1 0}$ & $\mathbf{2 0 1 0 / 2 0 4 0}$ & $\mathbf{2 0 4 0 / 2 0 7 0}$ & $\mathbf{2 0 7 0 / 2 1 0 0}$ & $\mathbf{1 9 8 0} / \mathbf{2 0 1 0}$ & $\mathbf{2 0 1 0 / 2 0 4 0}$ & $\mathbf{2 0 4 0 / 2 0 7 0}$ & $\mathbf{2 0 7 0 / 2 1 0 0}$ \\
\cline { 2 - 9 } & $\mathrm{T}[\%]$ & $\mathrm{T}[\%]$ & $\mathrm{T}[\%]$ & $\mathrm{T}[\%]$ & $\mathrm{P}[\%]$ & $\mathrm{P}[\%]$ & $\mathrm{P}[\%]$ & $\mathrm{P}[\%]$ \\
\hline smhirca & 100 & 102.70 & 111.63 & 116.67 & 100 & 100.35 & 103.93 & 99.63 \\
\hline $\mathbf{d m}$ & 100 & 103.72 & 111.29 & 120.81 & 100 & 106.01 & 109.74 & 113.54 \\
\hline knmiracmo2 & 100 & 119.19 & 125.56 & 130.89 & 100 & 81.77 & 90.30 & 79.68 \\
\hline remo & 100 & 105.61 & 116.77 & 128.18 & 100 & 107.67 & 103.97 & 114.39 \\
\hline \hline Average & $100(7.12)$ & $\begin{array}{c}107.81 \\
(7.52)\end{array}$ & $\begin{array}{c}116.31 \\
(7.40)\end{array}$ & $\begin{array}{c}124.14 \\
(7.51)\end{array}$ & $100(39.24)$ & $\begin{array}{c}98.95 \\
(41.56)\end{array}$ & $\begin{array}{c}101.98 \\
(41.69)\end{array}$ & $\begin{array}{c}101.81 \\
(43.04)\end{array}$ \\
\hline
\end{tabular}

For the 8-year calibration period, the $\mathrm{ET}_{\mathrm{M}}$ was $43.8 \mathrm{~mm}$ in the case of the mixed parcel, whereas for the forested area, it was 51.2 $\mathrm{mm}$. The average soil moisture $\left(\mathrm{SOIL}_{\mathrm{M}}\right)$ was $196.7 \mathrm{~mm}$ (mixed parcel), and $404.6 \mathrm{~mm}$ (forested area); however, the minimum values of the soil moisture were: $78.3 \mathrm{~mm}$ (mixed parcel) and $232.3 \mathrm{~mm}$ (forested area).

\subsection{Projection}

The next step was projecting with the 4 regional climate models (RCMs). The main properties of the RCMs used can be found in Table 2 .

Tab. 2: The RCMs applied (Jacob 2001; Jacob et al., 2007; Christensen and van Meijgaard, 1992; Christensen et al. 1996; Jones et al., 2004).

\begin{tabular}{|c|c|c|c|c|}
\hline $\begin{array}{c}\text { Research } \\
\text { Institute }\end{array}$ & RCM & GCM & Scenario & Resolution \\
\hline MP_I & REMO & ECHAM5 & A1B & $25 \mathrm{~km}$ \\
\hline KNMI & RACMO2 & ECHAM5-r3 & A1B & $25 \mathrm{~km}$ \\
\hline DMI & HIRHAM5 & ECHAM5 & A1B & $25 \mathrm{~km}$ \\
\hline SMHI & RCA & ECHAM5-r3 & A1B & $25 \mathrm{~km}$ \\
\hline
\end{tabular}

The model's time scales cover a range from 2000 to 2100. Each of them contains temperature and precipitation data in monthly time intervals, whereby the evapotranspiration can be calculated. To evaluate the results for the 21 st century, we have divided it into 4 main investigational periods: $1980-2010 ; 2010-2040 ; 2040-2070$ and $2070-$ 2100.
For each of the time intervals, and models, the basic descriptive statistics were evaluated.

In our case, the soil moisture does not mean the total amount of water in the soil, but the total amount available for the vegetation.

\subsection{Water stress}

To assess the water stress, the relative extractable water (REW) needed to be calculated using the following equation (Granier et al., 1998):

where:

$$
\mathrm{REW}=\frac{\mathrm{EW}}{\mathrm{EW}_{\mathrm{m}}}
$$

REW: relative extractable water [dimensionless],

EW: extractable water [mm],

$\mathrm{EW}_{\mathrm{m}}$ : maximum extractable water in the soil $[\mathrm{mm}]$

When the (R)EW drops below $40 \%$ of the $\mathrm{EW}_{\mathrm{M}}$, the transpiration is progressively reduced due to stomatal closure; hence, water stress is assumed to occur.

In our case, the $\mathrm{EW}_{\mathrm{m}}$ is equivalent to the $\mathrm{SOIL}_{\mathrm{MAX}}$ values because it is the maximal amount of water available to plants, while the EW is equal to the soil moisture averages $\left(\mathrm{SOIL}_{\mathrm{M}}\right)$ in the different investigational periods.

$$
\mathrm{SWD}=\mathrm{EW}_{\mathrm{m}} \cdot 0.4-\mathrm{EW}
$$

If $\mathrm{EW}<0.4 * \mathrm{EW}_{\mathrm{m}}$ and, for that very reason the SWD values are positive, water stress is assumed to occur.

where:

$$
\mathrm{I}_{\mathrm{S}}=\frac{\sum \mathrm{SWD}}{\mathrm{EW}_{\mathrm{m}}}
$$

SWD: soil water deficit [mm],

$\mathrm{I}_{\mathrm{s}}$ : annual water stress index [dimensionless]. 


\section{RESULTS AND DISCUSSION}

Three of the RCMs project increasing rates of evapotranspiration, but each model predicts decreasing rates for soil moisture at the end of the 21 st century. The 'Remo' model projects the highest increasing rates of evapotranspiration $\left(\mathrm{ET}_{\mathrm{M}}\right)$ (Figure 5).

The values of these increases in $\mathrm{ET}_{\mathrm{M}}$ are $+18 \%$ (mixed parcel) and $+19 \%$ (forested area). These rates increase significantly in the first part of the $21^{\text {st }}$ century $(+7.5 \%)$, but only slightly at the end of the century $(+2.5 \%)$.

In contrast to the previously mentioned tendency, the 'knmiracmo2' model shows decreasing $\mathrm{ET}_{\mathrm{M}}$ rates in the last 30 years of the $21^{\text {st }}$ century for both of the cover types. The reason is that the 'knmiracmo2' model projects the highest increasing rates of temperature, but the highest decreasing rates of precipitation (Table 2); consequently, there will be insufficient water for evaporation (i.e., a high degree of difference between actual and temperature-based potential evapotranspiration).

The projected soil moisture percentages of the models are $-12 \%$ (mixed parcel) and -11\% (forested area). The 'Knmiracmo2' has the strongest recession rate for both the mixed parcel and forested areas. For both cover types, the 'dm' model projects the lowest decreasing rate. In contrast to the $\mathrm{ET}_{\mathrm{M}}$ rates, the soil moisture rates decrease slightly in the first part of the $21^{\text {st }}$ century $(-5 \%)$, but this decreasing tendency will be more significant at the end of the century $(-7 \%)$ because of the intense scarcity of water.

The plots (Figure 6) for the ' $\mathrm{SOIL}_{\mathrm{M}}$ ' minimum are important in the context of the minimum soil moisture available for the plants. The 'knmiracmo2' model projects the lowest soil moisture minimum rates for both study areas: $-20 \%$ for the mixed parcel and $-40 \%$ for the forested area (Figure 6). We have found that the minimum values mainly appear in the months of September and October.
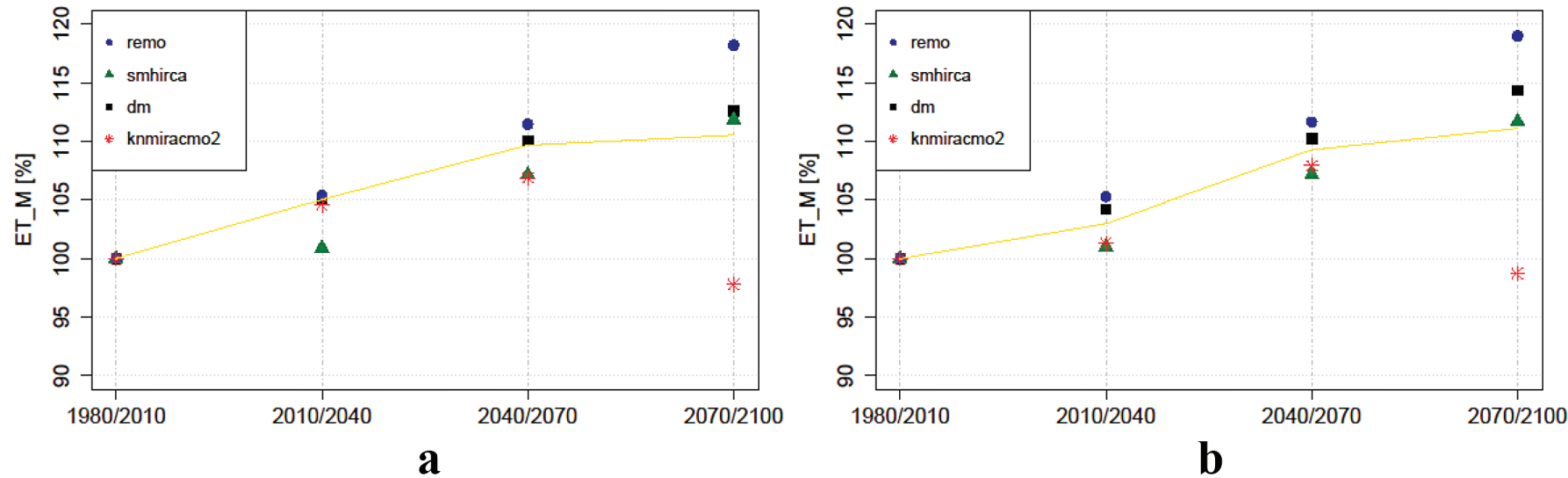

Fig. 5: The projected averages of evapotranspiration for the mixed parcel (a) and forested area (b) between 2001-2100.

Tab. 4: $E T_{M} ; S O I L_{M} ; \& O I L_{M}$ Min., ratio and standard deviations for the mixed parcel and forested area.

\begin{tabular}{|c|c|c|c|c|}
\hline \multirow{2}{*}{ Parameters } & $1980 / 2010$ & $2010 / 2040$ & $2040 / 2070$ & $2070 / 2100$ \\
\hline & {$[\%]$} & {$[\%]$} & {$[\%]$} & {$[\%]$} \\
\hline $\mathbf{E T}_{\mathrm{M}}$ of mixed parcel & $100(32.59)$ & $105(34.53)$ & $110(35.84)$ & $111(35.87)$ \\
\hline $\mathbf{E T}_{\mathrm{M}}$ of forested area & $100(36.32)$ & $103(37.62)$ & $109(39.21)$ & $111(39.40)$ \\
\hline SOIL $_{M}$ of mixed parcel & $100(42.6)$ & $95(48.36)$ & $94(53.35)$ & $88(60.81)$ \\
\hline $\mathrm{SOIL}_{\mathrm{M}}$ of forested area & $100(62.48)$ & $95(66.69)$ & $92(74.30)$ & $89(82.21)$ \\
\hline SOIL $_{M}$ Min. of mixed parcel & 100 & 84 & 80 & 52 \\
\hline SOIL $_{M}$ Min. of forested area & 100 & 89 & 92 & 68 \\
\hline
\end{tabular}

Tab. 5: Rates of stressed months in the context of SWD for the study areas.

\begin{tabular}{|c|c|c|c|c|c|}
\hline Study Areas & Model & $1980 \backslash 2010[\%]$ & $2010 \backslash 2040[\%]$ & $2040 \backslash 2070[\%]$ & $2070 \backslash 2100[\%]$ \\
\hline \multirow{4}{*}{ Forested area } & remo & 0 & 0 & 0 & 0.01 \\
\hline & $\mathrm{sm}$ & 0 & 0 & 0 & 0 \\
\hline & $\mathrm{dm}$ & 0.01 & 0.01 & 0 & 0.01 \\
\hline & knmi & 0.07 & 0.36 & 0.29 & 0.57 \\
\hline \multirow{4}{*}{ Mixed parcel } & remo & 0 & 0 & 0 & 0.03 \\
\hline & sm & 0 & 0 & 0 & 0 \\
\hline & $\mathrm{dm}$ & 0.07 & 0.07 & 0.07 & 0.11 \\
\hline & knmi & 0.08 & 0.46 & 0.40 & 0.61 \\
\hline
\end{tabular}



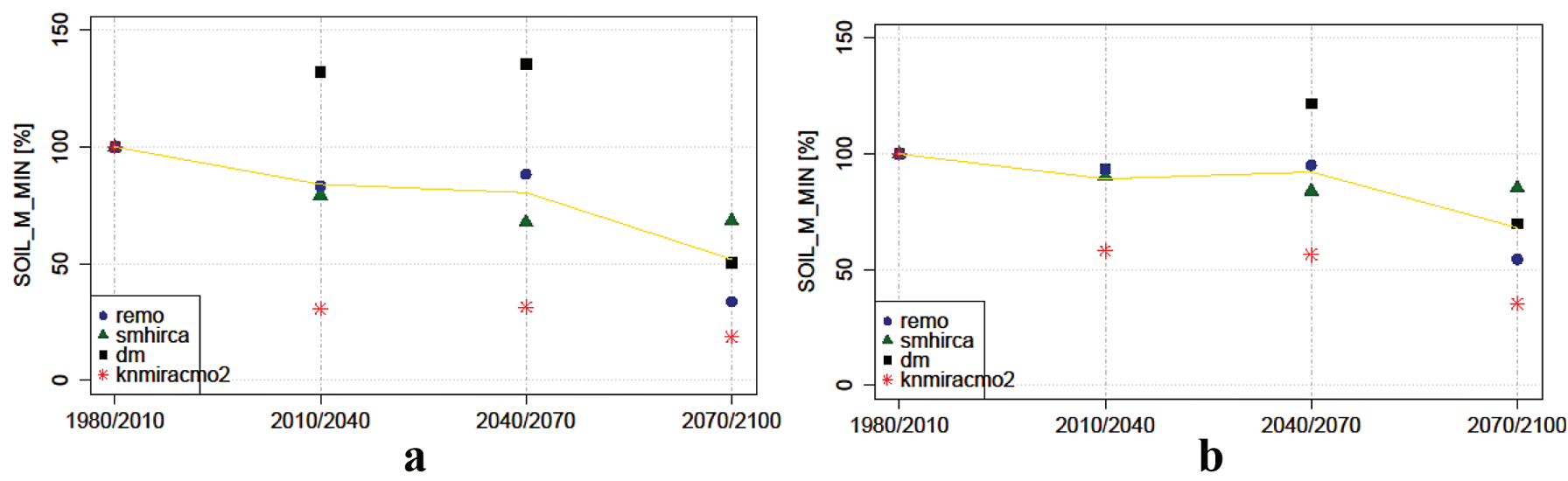

Fig. 6: The projected minimum values of soil moisture for the mixed parcel (a) and forested area (b) between 2001-2100.

Vörösmarty et al. (1998) used a method similar to ours; therefore, we will briefly outline their work here. They compared 11 potential evapotranspiration methods in a global-scale water balance model. This comparison was aimed at determining the adequacy and suitability of the various evapotranspiration models. Areas of the continental United States were used for the comparison. The set contains reference surface methods, for instance, Thornthwaite or Hamon algorithms, and surface-dependent models, such as the Priestley and Taylor method.

They used 679 sites. The types of sites can mainly be divided into two major groups: cultivated and non-cultivated (e.g., grassland, broadleaf forests, etc.) surfaces.

Each potential evapotranspiration algorithm was compared with the difference between the grid precipitation $(\mathrm{P})$ and mean measured runoff $(\mathrm{Qm})$. To determine the annual values for bias, they used the $\beta \mathrm{e}=\mathrm{Es}-(\mathrm{P}-\mathrm{Qm})$ equation, where $\beta \mathrm{e}$ is the mean annual bias, and Es is the simulated evapotranspiration.

In the case of $\beta$ e, the Thornthwaite algorithm showed the lowest values (an overall bias of $-84 \mathrm{~mm} \mathrm{yr}^{-1}$.) out of the 11 methods and nearly always provided underestimates, especially in the case of the cultivated cover type. However, the Thornthwaite algorithm usually gave commonly unbiased results or small underestimations if the evaporation was no more than $900 \mathrm{~mm} \mathrm{yr}^{-1}$.

The Hamon model also shows underestimations. Hamon generally evaluated unbiased results for cultivated land. For the Thornthwaite and Hamon methods, the broadleaf estimates were quite precise. Of the reference surface methods tested, the Hamon model had the smallest bias.

Granier et al. (1999) established a daily lumped water balance model for forest stands with the aim of quantifying the intensity and duration of droughts in different regions of France.

Their model is also more robust than ours since they used potential evapotranspiration (Penman-Monteith instead of Hamon), precipitation (climate data), and a leaf area index as well as the maximum extractable water (site and stand parameters) as input parameters. The model computed stand transpiration, interception, and soil water content. Granier et al. (1999) regarded a soil profile as several horizontal layers. However, they stated that the soil profile could be considered as one layer if there was not enough information available about its characteristics, as was the case with ours. Sap flow measurements of the stand transpiration were completed for the calibration, while the validation was performed by a comparison of the measured and simulated soil water at weekly frequencies.

Granier et al., (1999) mentioned some values for $\mathrm{EW}_{\mathrm{M}}: 180 \mathrm{~mm}$ (coniferous stand with deep soil), $185 \mathrm{~mm}$ (broad-leaved stands with deep soil), and $72 \mathrm{~mm}$ (broad-leaved stands with shallow soil). Ac- cording to their figures, the REW values did not drop below the 0.4 threshold in the case of deep soil, not even in the months when its lowest values occurred (mainly in August and September) in the wettest years. Nevertheless, the REW values dropped below 0.4 in the driest years, not just in areas with shallow soil, but also in areas with deep soil. In our case, we have very deep soil (with $2.5 ; 4.5 \mathrm{~m}$ was the vertical extent of the root zone) and consequently high $\mathrm{EW}_{\mathrm{M}}$ (SOILMAX in our case) values (described in the 'Calibration of the actual evapotranspiration' subchapter). We concluded that the water stress also occurred in the months of August and September. Our model showed less water stress in the case of the forested area, both in the calibration and projection phases. The reason for this better condition is the deeper root zone, which, consequently, means more available water for the plants.

Furthermore, the REW values decrease circa $10 \%$ in each of the study areas (from $88 \%$ to $78 \%$ ) (eq. 11 ) in the $21^{\text {st }}$ century.

In the context of SWD, and for that very reason, $\mathrm{I}_{\mathrm{S}}$ (eqs. 12 and 13), we saw that the 'knmiracmo2' is the most pessimistic RCM since it projects that $\sim 60 \%$ of the months in the $2070 / 2100$ period will be stressful (Table 5). Curiously enough, 'smhirca' does not project even a single month with water stress for the $21^{\text {st }}$ century.

\section{CONCLUSIONS}

We developed a model based on Thornthwaite-type monthly water balance estimations using remote sensing-based evapotranspiration as a calibration parameter.

The advantage of our model is its robust structure; therefore, it can be applied even if only temperature and precipitation values are available. The parameter of the calibration is the (maximal) soil-water storage capacity of the soil ( $\mathrm{SOIL}_{\mathrm{MAX}}$ ).

Primarily, the model can be used in a catchment level or for areas without additional water amounts from the surface or subsurface.

The model was successfully calibrated for a mixed parcel near Mosonmagyaróvár, Hungary, and for a forested catchment near Sopron, Hungary. After the calibration, the temperature and precipitation datasets of the four regional climate models were used for the projection of the water balance parameters, as well as for the water stress calculations.

Each of the models projected slightly ascending evapotranspiration values (both study areas: $11 \%$ ), but strongly decreasing soil moisture minimum values (mixed parcel: $-48 \%$; forested area: $-32 \%$ ) for the end of the $21^{\text {st }}$ century.

Less water stress was projected in the case of the forested area, both in the calibration and the projection phases. The better condi- 
tions for the forests can be explained by the more reachable water resources in the deeper soil layers (utilized by a deeper root system).

In context of the water management, the determination of water availability will be a key step, particularly in the future climate change. Consequently, water-balance modeling serves as a good basis to improve the water management and therefore irrigation performance. Both are critical to ensure the availability of water for food production and environmental needs. Nevertheless, the practices that enhance the efficiency of irrigations can be provided significant adaptation potential for all land production for the climate change in the future.

Our study is a being part of the larger ongoing project Agroclimate.2. Therefore this article was the first step to provide a basis to the decision-support system of that project in the context of water management. However, this work was only a baseline investigation in this present phase, where a relatively straightforward water-balance model was adapted and utilized in regional conditions. Therefore, on this basis, further research issues have to be accomplished.

\section{Acknowledgement}

This research has been supported by Agrárklíma.2 (VKSZ_12-12013-0034) EU-national joint founded research project.

\section{REFERENCES}

Bartholy, J. - Bozó, L. - Haszpra, L. (2011) Klímaváltozás - 2011 Klímaszcenáriók a Kárpát-medence térségére (Climate change - 2011, Climate scenarios in the area of the Carpathian basin). Magyar Tudományos Akadémia, Eötvös Loránd Tudományegyetem Meteorológiai Tanszék, ISBN 978-963-284-232-5.

Christensen, J.H. - Christensen, O.B. - Lopez, P. - Van Meijgaard, E. - Botzet, M. (1996) The HIRHAM4 regional atmospheric climate model. DMI Technical Report 96-4. Available from DMI, Lyngbyvej 100, Copenhagen Ø.

Christensen, J.H. - Van Meijgaard, E. (1992) On the construction of a regional atmospheric climate model. DMI Technical Report 92-14. Available from DMI, Lyngbyvej 100, Copenhagen Ø.

Dövényi, Z. (2010) Magyarország kistájainak katasztere - második, átdolgozott és bővitett kiadás, MTA (Inventory of microregions in Hungary).

Dingman, L. S. (2002) Physical Hydrology. Prentice-Hall. ISBN 0-13-099695-5, pp. 646

Gálos, B. - Vig, P. (2014) Éghajlati tendenciák a Kárpát-medencében és Zala megyében in: Agrárklíma Az elörevetített klímaváltozás hatáselemzése és az alkalmazkodás lehetöségei az erdészeti- és agrárszektorban (Climate tendencies in the Carpathian Basin and Zala county: an assessment of the impact of the projected climate change and the chance for adaptation in the forestry and the agrarian sector). Sopron, 2014.

Granier, A. - Breda, N. - Biron, P. - Villette, S. (1999) A lumped water balance model to evaluate duration and intensity of drought constraints in forest stands. Ecological Modelling, 116, pp. 269-283.

Guitjens, J. C. (1982) Models of alfalfa yield and evapotranspiration. J. Irrig. and Drainage Division ASCE 108(3), pp. 212-222.

Dai, Z. - Li, C. - Trettin, C. - Sun, G. - Amatya, D. - Li, H. (2010) Bi-criteria evaluation of the MIKE SHE model for a forested watershed on the South Carolina coastal plain. Hydrol. Earth Syst. Sci. 14(1), pp. 1-14.

Hamon, W. R. (1963) Computation of direct runoff amounts from storm rainfall. Intl. Assoc. Scientific Hydrol. Publ. 63, pp. 52-62.

Hlavčová, K. - Lapin, M. - Valent, P. - Szolgay, J. - Kohnová, S. Rončák, P. 2015) Estimation of the Impact of Climate Change-Induced Extreme Precipitation Events on Floods. Contributions to Geophysics and Geodesy, vol. 45, no. 3, pp. 173-192.
HREX report, (2012) Eghajlati szélsőségek változásai Magyarországon: Közelmúlt és jövő. (Extreme climate changes in Hungary: the recent past and future). Lakatos, M. -Szépszó, G. - Bihari, Z. - Krüzselyi, I. - Szabó, P. - Bartholy, J. - Pongrácz, R. - Pieczka, I. - Torma, C. (eds.) http://www.met.hu/doc/IPCC jelentes/HREX_jelentes-2012.pdf

IPCC, (2014) Summary for Policymakers. In: Edenhofer, O. Pichs-Madruga, R. - Sokona, Y. - Farahani, E. - Kadner, S. Seyboth, K. - Adler, A. - Baum, I. - Brunner, S. - Eickemeier, P. - Kriemann, B. - Savolainen, J. - Schlömer, S. - von Stechow, C. - Zwickel, T. - Minx, J.C. (eds.) Climate Change 2014, Mitigation of Climate Change. Contribution of Working Group III to the Fifth Assessment Report of the Intergovernmental Panel on Climate Change Cambridge University Press, Cambridge, United Kingdom, and New York, NY, USA.

Jacob, D. - Barring, L. - Christensen, O.B. - Christensen, J.H. Castro, M. - DeUe, M. - Giorgi, F. - Hagemann, S. - Hirschi, M. - Jones, R. - Kjellström, E. - Lenderink, G. - Rockel, B. - Sanchez, E. - Schar, C. - Seneviratne, S.I. - Somot, S. Van Ulden, A. - Van Den Hurk, B. (2007) An inter-comparison of regional climate models for Europe: model performance in present-day climate. Clim Change, 81, pp. 31-52, doi: 10.1007/s 10584-006-9213-4.

Jacob, D. (2001) A note to the simulation of the annual and inter-annual variability of the water budget over the Baltic Sea drainage basin. Meteorol. Atmos. Phys., vol. 77, pp. 61-73.

Jones, C. G. - Ullerstig, A. - Willen, U. - Hansson, U. (2004) The Rossby Centre regional atmospheric climate model (RCA). Part I: model climatology and performance characteristics for present climate over Europe. Ambio, vol. 33, nos. 4-5, pp. 199-210.

Kisházi, P. - Ivancsics, J. (1985) Sopron Környéki Üledékek Összefoglaló Földtani Értékelése (Geological Assessment of Sediments in the Neighbourhood of Sopron). Manuscript, Sopron, 48 pp.

Kovács, Á. (2011) Tó- és területi párolgás becslésének pontositása és magyarországi alkalmazásai (Specifying lake and areal evapotranspiration rates in Hungary). $\mathrm{PhD}$ értekezés. Budapesti Müszaki és Gazdaságtudományi Egyetem.

Maidment, D. R. (1993) Handbook of Hydrology. McGraw-Hill Education; 1 st edition.

Marosi, S. - Somogyi, S. (eds.) (1990) Magyarország Kistájainak Katasztere I. (Cadastre of Small Regions in Hungary I.) MTA Földrajztudományi Kutató Intézet, Budapest, 479 pp. 
Mingteh, Ch. (2006) Forest Hydrology: An introduction to water and forests (2nd. ed.), Stephen F. Austin State University, Texas, U.S.A., $181 \mathrm{pp}$.

Morton, F.I. - Ricard, F. - Fogarasi, S. (1985) Operational estimates of areal evapotranspiration and lake evaporation - Program WREVAP. National Hydrological Research Institute Paper \#24, Ottawa, Ontario, Canada.

Neilson, R. (1995) A model for projecting continental-scale vegetation distribution and water balance. Ecological Applications, vol. 5, no. 2, pp. 362-385

R Core Team (2012) $R$ : A language and environment for statistical computing. R Foundation for Statistical Computing, Vienna, Austria. ISBN 3-900051-07-0, URL http://www.R-project.org/.

Sun, G. K. - Alstad, J. - Chen, S. - Chen, C. R. - Ford, G. - Lin, C. - Liu, N. - Lu, S. G. - McNulty, H. - Miao, A. - Noormets, J. M. - Vose, B. - Wilske, M. - Zeppel, Y. - Zhang Z. (2011) A general projective model for estimating monthly ecosystem evapotranspiration. Ecohydrol., vol. 4, no. 2, pp. 245-255.

Szilágyi, J. - Józsa, J. (2008) Klímaváltozás és a víz körforgása (Climate change and watercycle). Magyar tudomány no. 6, pp. 698-703.

Szilágyi, J. - Kovács, Á. (2010) Complementary-relationship-based evapotranspiration mapping (CREMAP) technique for Hungary. Periodica Polytechnica - Civil Engineering, vol. 54, no. 2, pp. 95-100.
Szilágyi, J. - Józsa, J. - Kovács, Á. (2011) A Calibration-Free Evapotranspiration Mapping (CREMAP) Technique, Evapotranspiration. Labedzki, L. (ed.) In Tech, ISBN: 978-953-307251-7. Available from: http://www.intechopen.com/books/ evapotranspiration/a-calibration-free evapo-transpiration mapping-cremap-technique.

Thornthwaite, C.W. (1948) An Approach toward a Rational Classification of Climate. Geographical Review, vol. 38, no. 1, pp. $55-94$.

Thornthwaite, C.W. - Mather, J.R. (1955) The water balance. Philadelphia, PA: Drexel Institute of Technology, Climatological Laboratory publication 8 .

Muggeo, V.M.R. (2008) Segmented: an R package to fit regression models with broken-line relationships. R News 8/1, pp. 20-25.

Vörösmarty, C. J. - Federer, C. A. - Schloss, A. L. (1998) Potential evaporation functions compared on US watersheds: Possible implications for global-scale water balance and terrestrial ecosystem modelling. Journal of Hydrology, 207, pp. 147-169.

Wilson, B.N. - Brown J.W. (1992) Development and evaluation of dimensionless unit hydrograph. Water Resource Bulletin, 28, pp. 397-408. 